\title{
Predicting the Persistence of Undeclared First-Year and Transfer Students
}

\author{
Sandra L. Dika, Kristina Siarzynski-Ferrer, Kristen Galloway, and Mark M. D'Amico
}

A significant proportion of students enter four-year institutions without declaring an academic major, and institutions have developed targeted advising and services to help these students select careers and persist to graduation. Previous research is dated and inconclusive about whether enrolling as undeclared has a negative effect on persistence, and there is little information about which pre-college attributes and early college experiences may serve as positive predictors of persistence for this student population. Utilizing a sample of 585 entering undeclared first-year and transfer students at a four-year public research institution, this study explores how well pre-entry attributes, early experiences, and integration predict persistence from initial enrollment to the third semester. Implications for future research and advising practices are discussed.

A small, but significant, proportion of first-year, first-time (FYFT) students enter higher education without declaring an academic major. Current national figures show that the undeclared major ranks 12 th in enrollment, about $2 \%$ of all FYFT students (NCES, 2014). When considering FYFT students that are undecided about their intended major-even when they have declared a major-the proportion jumps to 10\% (Eagan, Lozano, Hurtado, \& Case, 2013). As an important first-year student subpopulation, undeclared students are considered to be at risk for poor academic performance because they lack clearly defined career or academic goals (Miller \& Woycheck, 2003). Institutions have developed various interventions to work with students who do not declare a specific academic major, including the concept of a "university college" that allows students to have an academic home and receive targeted advising and services to improve persistence and decidedness. However, previous research on the persistence of undeclared students is generally dated and has shown some conflicting results.

Some early studies conducted using longitudinal data sets from the 1980s

Sandra L. Dika (sdika@uncc.edu) is an Assistant Professor of Educational Research at the University of North Carolina at Charlotte

Kristina Siarzynski-Ferrer is a Doctoral Student in Educational Leadership at the University of North Carolina at Charlotte

Kristen Galloway is a Doctoral Student in Educational Leadership at the University of North Carolina at Charlotte

Mark M. D'Amico is an Associate Professor of Educational Leadership at the University of North Carolina at Charlotte 
did not find persistence differences between undeclared students and those with majors (e.g., Anderson, Creamer, \& Cross, 1989; Lewallen, 1993; 1995). Additionally, researchers found that characteristics of undeclared students were not significantly different from those who declared majors (Gordon \& Steele, 2003); however, this research is over a decade old. Other studies using nationally representative data from the 1990s found lower persistence to second year (Leppel, 2001) and to graduation (Titus, 2006) for undeclared students compared with those in majors. The lack of consistency among the studies using data from previous decades demonstrates the need for more current research on the persistence of undeclared students, taking into account their pre-enrollment attributes and experiences during the beginning of the first year, an important time of transition for college students.

Further, recent attention from the White House and other advocacy groups and foundations on the importance of successful transfer (Handel \& Williams, 2012) necessitates additional inquiry into the persistence of transfer students entering as undeclared majors and implications for institutions. In Gordon and Steele's (2003) 25-year longitudinal study, 10\% of undeclared students were transfer students, and that number may be significantly higher in today's higher education environment, with swirling enrollment patterns. Studies conducted using large representative national data sets (Beginning Postsecondary Study; Cooperative Institutional Research Program) include "declared major" as a variable and do not include transfer students in their samples, so it is unclear whether the factors in persistence of undeclared transfer students are similar to those of undeclared firstyear students.

The purpose of this study is to investigate how well pre-entry demographic and academic attributes, early experiences, and early academic and social integration predict persistence among undeclared students entering a university college at a four-year public research university. We propose separate models for first-year and transfer students to acknowledge that the factors and experiences leading to persistence may differ for these groups. In this study, we refer to these students as "undeclared" as that is the best descriptor, given their status at the institution under study.

\section{Conceptual Model of Persistence of Undeclared Students}

The framework for this study assumes that factors associated with persistence of entering undeclared students may be different than those of their peers who have declared majors. As such, the framework incorporates both Tinto's (1993) Longitudinal Model of Institutional Departure along with research on the nature of decidedness and the undeclared student population to identify variables associated with persistence of undeclared students (Figure 1).

Tinto's (1993) model identifies a number of causes of student withdrawal from institutions of higher education. Lack of clear academic and career goals can have an impact on students' intention and commitment to stay and graduate from their original college or university. Both prior to and during enrollment at the 


\section{Conceptual Model: Undeclared Student Persistence}

\begin{tabular}{|l|l|}
\hline $\begin{array}{l}\text { Demographic } \\
\text { Background }\end{array}$ & $\begin{array}{l}\text { Academic } \\
\text { Background }\end{array}$ \\
Gender \\
Race/ethnicity & $\begin{array}{l}\text { Parent } \\
\text { education } \\
\text { Prep in math } \\
\text { Prep in writing } \\
\text { Predicted/ } \\
\text { transfer GPA }\end{array}$ \\
\hline
\end{tabular}

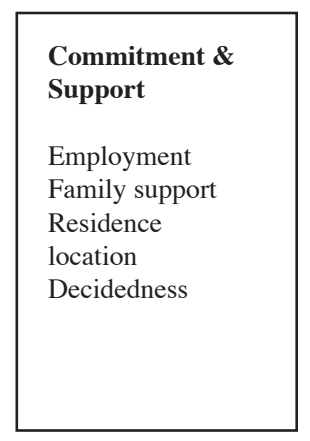

\begin{tabular}{|l|}
\hline $\begin{array}{l}\text { Institutional } \\
\text { Experiences }\end{array}$ \\
Academic \\
Engage advisor \\
First-year/ \\
Transfer seminar \\
Social \\
Participation in \\
club or sport \\
\end{tabular}

\begin{tabular}{|l|} 
Perceived \\
Early \\
Integration \\
Academic fit \\
Social fit \\
\\
\\
\end{tabular}

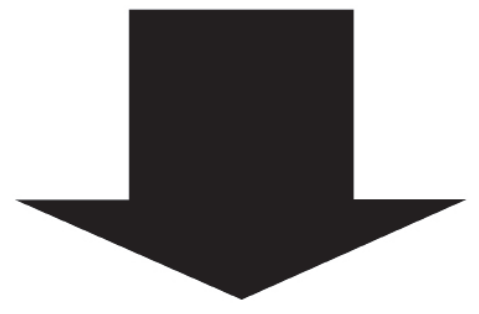

Persistence

Third semester enrollment

institution, experiences of adjustment, difficulty, incongruence, and isolation also affect student persistence.

Research on the undeclared student population dates back to the mid-1960s (Ashby, Wall, \& Osipow, 1966) and emphasizes the degree to which students define their academic and career goals. Research on this population incorporates multiple frameworks of student development, particularly development theory (Baxter-Magolda, 1992; Gordon, 1981; Perry, 1999). Developmental theory suggests that rather than searching for an academic calling or career, undeclared students are participating in techniques to help prepare them to make decisions and become adaptable in a changing climate (Gordon, 2007). Gordon (1998) identified seven "decision status" categories for career decisions on a continuum of very decided, somewhat decided, unstable decided, developmentally undecided, seriously undecided, and chronically indecisive.

The major elements of the model for our study-demographic and academic background, commitment and support, institutional experiences, perceived early integration, and persistence-are drawn from Tinto's (1993) theory. The specific 
variables selected within each element consider the research on undeclared students and on underrepresented students in general. For commitment and support, student satisfaction with major is a proxy for decidedness to understand how students feel about being in the undeclared major.

\section{Background Characteristics, Experiences, Engagement, and Academic Outcomes of Undeclared Students}

Published studies on the predictors of persistence and outcomes of undeclared college students are surprisingly few in higher education literature. Much of the research that looks more broadly at students who are "undecided" tends to be dated and is concentrated in publications in the vocational counseling and advising fields, emphasizing advising practices and interventions. Despite the limited focus, studies conducted during the past three decades provide some insight into how demographic and academic background, commitment and support, academic experiences, and engagement are linked to transitions and outcomes for undeclared students. The terms "undecided" or "undeclared" are used interchangeably by some authors to refer to students who have not declared a major, while in other studies, the term "undecided" refers to level of decidedness (e.g., Gordon, 2007). In our review, we included only studies that focused on students who had not declared a major to best align with the sample we examine in our study.

\section{Background Characteristics}

The demographic characteristics and academic background of undeclared students may be different than their peers who declare a major. Nationally representative data suggest that students in the lower two socioeconomic (SES) quartiles are significantly more likely to have an undeclared major at the end of their first year than students in the third and fourth SES quartiles (Titus, 2006); however, there may be fewer demographic and academic differences between undeclared and declared majors within the same institution (e.g., Anderson et al., 1989). Within the undeclared student population, there is some evidence to suggest that persistence may be related to demographic characteristics. In a study of the Indiana higher education system, first-year White students who had not declared a major were less likely to persist than their peers with declared majors, but there were no differences in likelihood to persist among first-year African American students based on major selection (St. John, Hu, Simmons, Carter, \& Weber, 2004).

\section{Institutional Experiences, Engagement, and Academic Outcomes}

There is limited research examining student involvement and engagement for undeclared students. In a pair of studies using longitudinal data from the 1985 
cohort of the Cooperative Institutional Research Program (CIRP), Lewallen (1993; 1995 ) found no difference in involvement, social interaction with peers, studentfaculty interaction, and persistence to graduation between entering students who had declared a major on entry and those who had not. However, later studies using large, multi-institutional data sets from the 1990s found that entering undeclared students had both lower expectations of involvement (College Student Expectations Questionnaire; Kuh, Gonyea, \& Williams, 2005) and reported lower levels of participation (Hu \& Kuh, 2002) than students who had declared a major.

Previous research relating declaration of major to academic performance and persistence shows mixed results. Two studies using longitudinal data from the 1985 Cooperative Institutional Research Program (CIRP) and its 1989 follow-up found that being undecided about a "probable major" was not related to lowered persistence for first time students (Lewallen, 1993; 1995). Similarly, longitudinal data from a public comprehensive university in Virginia also suggested that entering as an undecided major had no negative effect on persistence and graduation (Anderson et al., 1993). However, entering students who did not declare a major were significantly less likely than peers in any other declared major to persist among the 1990 (Leppel, 2001) and 1995 (Titus, 2006) cohorts of the Beginning Postsecondary Study (BPS). A single-state study in Indiana (St. John et al., 2004) also found a lower likelihood to persist among undeclared students, but only for White students.

Some important characteristics of the extant literature should be emphasized. Studies using nationally representative data generally find lower likelihood to persist for undeclared first-time students. However, these studies are dated and based on cohorts from previous decades that are not representative of the current college population that displays more ethnic, socioeconomic, and age diversity. Further, all of the studies are focused on the first-year, first-time (FYFT) population and do not consider transfer status. Scholars have proposed revisions to Tinto's (1993) model for non-traditional student groups, including firstgeneration students (e.g., Martinez, Sher, Krull, \& Wood, 2009), underrepresented racial and ethnic minorities (e.g., Palmer, Davis, \& Maramba, 2011), and transfer students (e.g., D'Amico, Dika, Elling, Algozzine, \& Ginn, 2014) to understand what contributes to student persistence within these groups, rather than simply concluding that they are groups that persist at lower rates. Considering that the prevailing model of student persistence also may not function in the same way for undeclared students, there is a need for studies that focus specifically on this subpopulation to identify the background characteristics, commitments, and institutional experiences that are associated with persistence.

\section{Methodology}

This study utilizes logistic regression to determine significant predictors of persistence among entering undeclared students at a four-year public research institution in the southeastern United States. Following the conceptual framework, 
we examined logistic regression models separately for FYFT and transfer students entering without a major to understand how well pre-college demographic and academic factors and early transitional experiences, including institutional experiences and academic and social integration, predict persistence.

\section{Setting, Data Sources, and Sample}

The setting for this study is a four-year urban research institution in the Southeast, with more than 20,000 undergraduate students enrolled during fall 2014. For the past several years, about half of the entering class has been comprised of transfer students. There are many colleges within the university with all but one offering degrees, and the other, a "university college," is dedicated to undeclared students.

In 2005, the institution used Tinto's (1993) student departure model, among others, to develop a survey aimed at capturing new students' academic preparation, expected performance, and engagement patterns about halfway through the semester after initial enrollment to understand how they are transitioning to the university environment. The survey was administered from Weeks 6 through 8 in order to capture data at the time when faculty members were evaluating students for mid-term grades. Since there were modifications to the survey throughout its use at the institution, we elected to use the three cohorts $(2008,2009$, and 2010) for which the items were identical. The data sources for the study included the selected items from the survey (described below) along with enrollment and persistence data from institutional records.

Undeclared college students are the target population of interest in this study, defined as FYFT or transfer students who are enrolled in the university college (UC). The sampling frame for the study included student records in the aforementioned database who were identified as being enrolled in UC ( $\mathrm{n}=707)$. In 2008-2010, the entering population for UC was about 1,110 students per year, meaning that slightly over $20 \%$ participated in the survey. The final sample for the logistic regression was based on listwise deletion of those records for which data on all of the study variables were not available; thus, the final sample size was 585 undeclared students: 293 FYFT and 292 transfer.

The demographic profile of the entire undeclared student sample included $50 \%$ FYFT and $50 \%$ transfer; $49 \%$ first-generation (neither parent with a four-year degree); $60 \%$ women; and, $70 \%$ White, $16 \%$ African American, and 14\% other race/ethnicity. About $78 \%$ resided in the metro area of the four-year institution (within 20 miles, including on-campus housing). Based on these data, the sample is considered representative of the undeclared student population at the institution.

\section{Variables}

We included five sets of potential predictors aligned to the conceptual model 
in this study. The majority of the independent variables were operationalized dichotomously to identify the presence or absence of each potential predictor of student outcomes. The item wording and descriptive statistics (frequencies or mean and standard deviation) for each variable is shown in Table 1 . The background variables included two demographic indicators (gender and race/ethnicity) and four academic background variables: (1) parent attainment of four-year degree, (2) perceived preparation in math, (3) perceived preparation in writing, and (4) the z-score of the students' predicted GPA (first-year students) or incoming transfer GPA (transfer students) to provide an estimate of academic preparation in relation to peers in the sample. To estimate the effects of student commitment and support, we included employment status (yes/no), emotional support and understanding from family members, whether the student was living on campus or within a mile (versus within 2-20 miles or over 20 miles from the institution), and whether the student was satisfied with his or her major. Institutional experiences included three variables: whether the student had ever met with a faculty member or academic advisor (academic), enrolled in a first-year or transfer seminar (academic), and participated in a club or sport (social). Perceived academic and social integration were each measured by student agreement with a single item on a five-point Likerttype scale. The lone dependent variable, persistence, was dichotomized to reflect whether or not the student was enrolled in the third semester.

TABLE 1

\section{Variable Labels, Descriptions, and Descriptive Statistics for Study Model Constructs, by Undeclared Student Status}

\begin{tabular}{|c|c|c|c|}
\hline Variable Labels & Item Wording or Description & $\begin{array}{l}\text { FYFT } \\
(\mathrm{F}, \mathrm{M}, \mathrm{SD})\end{array}$ & $\begin{array}{l}\text { Transfer } \\
(\mathrm{F}, \mathrm{M}, \mathrm{SD})\end{array}$ \\
\hline Gender & Gender code from student records & $\begin{array}{l}\text { Female }=62.5 \% \\
\text { Male }=37.5 \%\end{array}$ & $\begin{array}{l}\text { Female }=56.5 \% \\
\text { Male }=43.5 \%\end{array}$ \\
\hline Race/ethnicity & Ethnicity code from student records & $\begin{array}{l}\text { White }=71.7 \% \\
\text { Other }=28.3 \%\end{array}$ & $\begin{array}{l}\text { White }=68.8 \% \\
\text { Other }=31.2 \%\end{array}$ \\
\hline First generation & $\begin{array}{l}\text { Have one or both parents graduated } \\
\text { with a four-year college degree? }\end{array}$ & $\begin{array}{l}\text { Yes }=51.5 \% \\
\mathrm{No}=48.5 \%\end{array}$ & $\begin{array}{l}\text { Yes }=47.3 \% \\
\text { No }=52.7 \%\end{array}$ \\
\hline Math prep & $\begin{array}{l}\text { How well did prior educational } \\
\text { experiences prepare you for } \\
\text { college in math? }\end{array}$ & $\begin{array}{l}\text { Well prepared } \\
=61.8 \% \\
\text { Not well prepared } \\
=38.2 \%\end{array}$ & $\begin{array}{l}\text { Well prepared } \\
=58.9 \% \\
\text { Not well prepared } \\
=41.1 \%\end{array}$ \\
\hline Writing prep & $\begin{array}{l}\text { How well did prior educational } \\
\text { experiences prepare you for college } \\
\text { in writing papers? }\end{array}$ & $\begin{array}{l}\text { Well prepared } \\
=64.8 \% \\
\text { Not well prepared } \\
=35.2 \%\end{array}$ & $\begin{array}{l}\text { Well prepared } \\
=72.9 \% \\
\text { Not well prepared } \\
=27.1 \%\end{array}$ \\
\hline $\begin{array}{l}\text { Predicted/ } \\
\text { transfer GPA }\end{array}$ & $\begin{array}{l}\text { Z-score of student predicted GPA } \\
\text { (first-year) or transfer GPA }\end{array}$ & $\begin{array}{l}M=0.00 \\
S D=1.00\end{array}$ & $\begin{array}{l}M=0.04 \\
S D=1.02\end{array}$ \\
\hline
\end{tabular}




\begin{tabular}{|c|c|c|c|}
\hline Variable Labels & Item Wording or Description & $\begin{array}{l}\text { FYFT } \\
(\mathrm{F}, \mathrm{M}, \mathrm{SD})\end{array}$ & $\begin{array}{l}\text { Transfer } \\
(\mathrm{F}, \mathrm{M}, \mathrm{SD})\end{array}$ \\
\hline Family support & $\begin{array}{l}\text { How often do you receive emotional } \\
\text { support from your family? AND } \\
\text { How often does your family } \\
\text { understand the demands of your } \\
\text { academic commitments? Range }=2-8\end{array}$ & $\begin{array}{l}M=6.52 \\
S D=1.50\end{array}$ & $\begin{array}{l}M=6.31 \\
S D=1.78\end{array}$ \\
\hline Residence & $\begin{array}{l}\text { Where do you live relative to } \\
\text { (institution)? }\end{array}$ & $\begin{array}{l}\text { Within } 20 \text { miles } \\
=83.6 \% \\
>20 \text { miles } \\
=16.4 \%\end{array}$ & $\begin{array}{l}\text { Within } 20 \text { miles } \\
=63.7 \% \\
>20 \text { miles } \\
=36.3 \%\end{array}$ \\
\hline Employment & Do you work? & $\begin{array}{l}\text { Yes }=28.3 \% \\
\text { No }=71.7 \%\end{array}$ & $\begin{array}{l}\text { Yes }=27.1 \% \\
\mathrm{No}=72.9 \%\end{array}$ \\
\hline Selected major & $\begin{array}{l}\text { Do you have a specific career goal } \\
\text { and related major selected? }\end{array}$ & $\begin{array}{l}\text { Yes }=41.6 \% \\
\text { No }=58.4 \%\end{array}$ & $\begin{array}{l}\text { Yes }=45.9 \% \\
\text { No }=54.1 \%\end{array}$ \\
\hline FY seminar & $\begin{array}{l}\text { Are you enrolled in any first year } \\
\text { or transfer seminar? }\end{array}$ & $\begin{array}{l}\text { Yes }=30.4 \% \\
\text { No }=69.6 \%\end{array}$ & $\begin{array}{l}\text { Yes }=0.3 \% \\
\text { No }=99.7 \%\end{array}$ \\
\hline Involvement & $\begin{array}{l}\text { Are you involved in at least } \\
\text { one club or sport? }\end{array}$ & $\begin{array}{l}\text { Yes }=59.0 \% \\
\text { No }=41.0 \%\end{array}$ & $\begin{array}{l}\text { Yes }=27.1 \% \\
\text { No }=72.9 \%\end{array}$ \\
\hline Engage advisor & $\begin{array}{l}\text { How many times have you met with } \\
\text { an academic advisor this semester? }\end{array}$ & $\begin{array}{l}\text { At least once }=38.6 \% \\
\text { Never }=61.4 \%\end{array}$ & $\begin{array}{l}\text { At least once }=63.7 \% \\
\text { Never }=36.3 \%\end{array}$ \\
\hline Academic fit & $\begin{array}{l}\text { I feel that this institution is a } \\
\text { good fit for me academically. }\end{array}$ & $\begin{array}{l}\mathrm{M}=4.13 \\
\mathrm{SD}=0.72\end{array}$ & $\begin{array}{l}M=4.02 \\
S D=0.88\end{array}$ \\
\hline Social fit & $\begin{array}{l}\text { I feel that this institution is a } \\
\text { good fit for me socially }\end{array}$ & $\begin{array}{l}M=3.89 \\
S D=0.98\end{array}$ & $\begin{array}{l}M=3.35 \\
S D=0.97\end{array}$ \\
\hline
\end{tabular}

\section{Analysis}

We estimated two separate logistic regression models using SPSS to evaluate the statistically significant predictors of persistence for undeclared FYFT and transfer students. We examined percent correctly classified, Nagelkerke $R^{2}$, and model chi-square for each model, while odds ratios $(\operatorname{Exp} B)$ were examined at the item level. The cut-off probability used for calculation of percent correctly classified was 0.5. All tests were evaluated at the $\alpha=0.05$ level.

\section{Findings}

Prior to running the logistic regression models, we ran chi-square tests and 
t-tests to determine whether there were any significant differences in demographic and academic background characteristics, support, experiences, integration, and persistence based on enrollment status (FYFT or transfer). Transfer students were significantly more likely than FYFT students to perceive they were well prepared in writing, to have met with an advisor and a faculty member within the first six weeks, and to work during their studies. In contrast, FYFT students were more likely to be enrolled in an orientation seminar course and to be participating in at least one club or sport. FYFT students indicated significantly stronger agreement with fitting in socially at the institution than transfer students. These results suggested the importance of running separate regression models for undeclared FYFT and transfer students.

Additionally, we ran chi-square tests to determine whether persistence depended on any of the demographic and academic background characteristics or early experiences. Working during college was associated with significantly lower rates of persistence, while participating in at least one club or sport was associated with significantly higher rates of persistence. Despite the fact there were no other significant differences in persistence based on our selected background factors, and due to the exploratory nature of the study, we chose to retain all items in the logistic regression models due to the differences between transfer and FYFT students on several of the variables.

\section{Predictors of Persistence for Undeclared FYFT and Transfer Students}

In the logistic regression model for undeclared FYFT students, $85 \%$ of students were correctly classified. The chi-square model was not statistically significant, $\chi 2(16)=32.74, p=.01$, a positive indicator for fit; Nagelkerke $R^{2}$ was 0.18 , evidencing limited fit of the model. Three predictors significantly improved odds of re-enrollment for FYFT students: being non-White $(\mathrm{OR}=2.45)$, perceived preparation in math $(\mathrm{OR}=2.89)$, and social fit $(\mathrm{OR}=1.66)$.

The model was clearly different for undeclared transfer students. Fewer transfer students $(75 \%)$ were correctly classified for third-semester enrollment, and the final model also showed more limited fit $\left(\chi 2(16)=19.66, p=.24\right.$ : Nagelkerke $R^{2}=$ $0.10)$. Male students $(\mathrm{OR}=2.29)$ and students who lived on campus, versus over 20 miles away $(\mathrm{OR}=2.20)$, were more likely to persist to the third semester.

\section{Discussion}

This study is significant given the dearth of recent studies on outcomes of undeclared students and for its consideration of FYFT and transfer students as different subpopulations of undeclared students. We discuss the findings in relation to the extant research and the implications of these findings for future research and advising practice.

Significant predictors for FYFT undeclared student persistence in our sample included race, math preparation, and perceived social fit. Non-white FYFT 


\section{Predictors of Persistence among Undeclared Students}

Predictors

$\begin{array}{cc}\text { FYFT } & \text { Transfer } \\ \text { Odds Ratio } & \text { Odds Ratio }\end{array}$

Demographic background

Male

0.81

$2.29 * *$

White

$0.41^{*}$

1.30

Academic and previous college background

Predicted/transfer GPA

1.13

1.02

First generation

0.24

1.04

Math prep

$2.89 *$

1.10

Writing prep

0.70

0.92

Commitment and support

Work

1.31

1.15

Family support

1.22

1.00

Local (Less than 20 miles)

0.63

1.48

Local (More than 20 miles)

0.82

$2.20^{*}$

Institutional experiences

Engage advisor

1.05

1.09

First-Year / Transition seminar

0.95

0.00

Club or sport

0.82

0.55

Perceived early integration

Academic fit

Social fit

$\begin{array}{ll}1.51 & 1.26 \\ 1.66^{*} & 0.88\end{array}$

$\mathrm{N}$

293

292

Percentage correctly classified

$84.60 \%$

$74.70 \%$

$\chi^{2}(\mathrm{df})$

$32.74(16)$

$19.66(16)$

Nagelkerke $R^{2}$

0.18

0.10

${ }^{*} p<.05,{ }^{* *} p<.01$

undeclared students were more likely to persist than their White counterparts in our sample, which compares with the finding in a recent Indiana state study (St. John et al., 2004), where being an undeclared major was a negative factor in persistence for White students, but not for African American students. While scholars have suggested that undeclared students may be at risk of academic failure because they do not have a clearly defined academic or career goal (Miller \& Woycheck, 2003), an examination of longitudinal data from the 1990s revealed no significant differences between the characteristics of declared and undeclared 
majors (Gordon \& Steele, 2003). Among the FYFT undeclared students in our sample, previous academic achievement was not a significant factor in persistence (and showed little variance in the sample); however, perceived math preparation was positively linked with persistence. Additionally, while theory and previous research on undeclared and undecided students suggest that "decidedness" may be an important factor in student persistence (e.g., Gordon, 1998; 2007), having a career goal or major selected did not increase likelihood to persist among FYFT or transfer undeclared students.

Previously, research using large data sets (College Student Expectations Questionnaire, CSXQ; College Student Experiences Questionnaire, CSEQ) indicated that entering undeclared students may have both lower expectations of involvement (Kuh, Gonyea, \& Williams, 2005) as well as lower levels of participation (Hu \& Kuh, 2002) than students who had declared a major. In our sample, perceived social fit was a positive predictor of persistence among FYFT undeclared students; however, belonging to a club or sport did not increase likelihood of persistence. Further, other studies have suggested that FYFT undeclared students are more likely to be from lower socioeconomic status backgrounds (Titus, 2006); however, the proportion of first-generation college students in our sample (50\%) was very similar to the proportion in the institution's overall population. In addition, parental educational attainment did not have a significant effect on the likelihood to persist among FYFT undeclared students.

Looking at transfer undeclared students separately, we found only two significant predictors of persistence: being male and living on campus (as compared to living more than 20 miles away). There is a lack of research comparing transfer to FYFT students in research on undeclared students; thus, it is difficult to interpret our findings in relation to existing research. Research looking at transfer students suggests that socio-academic integration may be an important predictor of persistence (D'Amico et al., 2014; Deil-Amen, 2011). This study did not include any socio-academic integration variables; however, students who live much farther from campus could perhaps have fewer opportunities to integrate with classmates and with the institution in general.

While a strength of this study was the separate examination of predictors of persistence for FYFT and transfer undeclared students, there are limitations associated with a single institution sample. We note that there was little variance on some variables (e.g., predicted/transfer GPA) and that we may not be able to detect the influence of other variables (e.g., parental attainment) due to homogeneity of the sample and lack of institutional variation (e.g., Anderson et al., 1989). Despite these limitations, our findings imply the need for additional research to promote better understanding of the current population of undeclared students and refined advising and orientation services to address their unique needs.

\section{Implications for Future Research}

Nearly a decade ago, Cuseo (2005) noted that "not much... is to be gained 
from ... categorizing students as either 'decided' or 'undecided' and computing correlations between this dichotomous variable and student retention" (p. 4) and that it may be more important to research the process of how students go about deciding on a major and when they reach these decisions during their college experience. Our study was conducted in the spirit of examining undeclared students as a population who may be studying for the first time or transferring from another institution and understanding what pre-college attributes and early experiences transitioning into the college environment contribute to their persistence. In general, there is a need for research that focuses on undeclared students as a population and examines the characteristics within this population. While Gordon and Steele (2003) suggested that undeclared students may not look different than the rest of the population, there is a need to understand these subpopulations in the context of today's higher education environment.

Future research on undeclared students should consider the concept of "decidedness" as an important factor in persistence and eventual selection of a major (Gordon, 1998; 2007). Due to limitations of our data set, we included "having a career goal or major selected" as a variable in our study, and did not find any increased likelihood to persist when students responded affirmatively. Future studies should include more nuanced measures of decidedness to delineate the extent to which students who have not declared a major are undecided in a career, major, or both. For transfer students, it would also be important to understand the nature of their enrollment (declared or undeclared), and decidedness at the prior institution would also help identify the level of intervention needed.

The nature of integration and engagement among undeclared students needs further study. In our study, while early participation in a club or sport did not contribute to increased likelihood to persist, perceived social fit was a significant factor for FYFT undeclared students. Additional research is necessary to understand what experiences or institutional climate factors contribute to feelings of social fit for undeclared students. Further, given research suggesting the unique nature of integration for transfer students (D'Amico et al., 2014; Deil-Amen, 2011), research that considers how socio-academic integration can contribute to persistence among undeclared transfer students is needed.

Future research must include empirical study, both quantitative and qualitative, of interventions for undeclared students. The concept of university college as a home for undeclared students has been around since the 1980s, but there has been little research published about the effectiveness of this model to promote persistence and selection of a major. Additionally, while a number of counseling and advising interventions can be found in the literature targeted at academic advisors, very few have been empirically studied. Notable exceptions are studies looking at the effects of tutoring (Reinheimer \& McKenzie, 2011), workshops on selecting a major (Legutko, 2007), and career development courses on academic success (Hansen \& Pedersen, 2012; Reynolds, Gross, Millard, \& Pattengale, 2010). We note the absence of studies on interventions specifically for undeclared transfer students. 
Completely different factors were significant in the persistence of the two groups of undeclared students in our study, suggesting that interventions should not be uniform for all undeclared students during their transition to declaring a major. Previous research, combined with the findings of this study, suggest considerations for academic advisors who work with undeclared FYFT and transfer students. We offer four primary suggestions for academic and career advising practitioners on the focus and delivery of services for undeclared students.

Ensure greater availability and accessibility of one-to-one advising services. A significant proportion of the students in our sample commuted from outside the metro area to the institution, including over one-third of undeclared transfer students. Advising practitioners should have an understanding of the available resources and programming for commuter undeclared students, both within and outside of their advising units. Directors of advising units should ensure the availability of advising during evening hours and via phone or Skype meetings to assist students who cannot make it during regular office hours.

Spend time discussing previous academic experiences and current needs with students. We found that perceived preparation in math contributed to persistence for FYFT undeclared students. Early identification of incoming students' math preparedness can provide proactive support by identifying possible barriers. Early conversations with students should address the comfort level in math and prior academic experience, including reviewing their academic transcript (Legutko, 2007). Providing students with campus resources, such as tutoring and supplemental instruction, and encouraging early intervention are important factors in helping students persist. Academic advisors should seek ways to integrate the work of other support services to help students during peak times of the semester, such as workshops after first exams, preparation sessions for midterm, and study groups during finals week.

The previous academic experiences of transfer students are clearly different than those of FYFT students. Wang (2009) found perceived locus of control and community college GPA as key predictors for persistence of students who transfer from two- to four-year institutions. While transfer GPA was not a significant predictor of persistence in our study, advisors should discuss academic experiences at the previous institution, including grades and academic and career goals. Discussing what was and was not helpful about advising services at the previous institution can also help advisors be more responsive to individual needs. Advisors can provide links to campus resources, such as tutoring and supplemental instruction, and encourage early intervention. Academic advisors should seek ways to integrate the work of other support services to help students during peak times of the semester, such as workshops after first exams, preparation sessions for midterm, and study groups during finals week.

Encourage involvement to increase integration at the institution. Researchers have long known that students who become involved in academic and social opportunities at the institution are more likely to persist (Tinto, 
1993). Advisors who work with undeclared students should be knowledgeable of campus clubs and organizations in order to accurately recommend and encourage student involvement in areas of their interest. In addition, academic advisors should encourage and participate in new student events that advertise student organizations. At some institutions, academic advisors serve as the instructors for first-year seminar courses and should invite campus resources to present to students.

Provide multiple opportunities to help students become decided about their major. Gordon's (1998) research emphasized the various levels of decidedness in students. Legutko's (2007) research focused on the attendance of undeclared students at a 2-hour workshop reviewing academic transcripts, general education, and major curriculum. The findings suggest that students who attended the workshop made informed decisions about their major and prevented students from declaring a major until they were ready (Legutko, 2007). In addition to brief opportunities, course-length interventions can also contribute to persistence and performance. Reynolds and colleagues (2010) conducted a mixed-methods study of a semester-long course on life calling and found that students were six times more likely to earn a degree after four years than those who did not take the course. The university was so overwhelmed by the improvement in student commitment and retention that they required all incoming students to complete the course. Similarly, Hansen and Pedersen (2012) looked at the effects of a career development course on outcomes, including adjustment, achievement, and persistence, finding that course completion was positively associated with each of these.

\section{Summary}

In light of the findings in the present study, we conclude by recognizing the important attention the higher education community has invested on student success. In recent years, the emergence of university college models have provided further evidence of institutional commitment to the undeclared student population, one that can indeed be vulnerable to lower levels of persistence. While additional study is needed, it is our hope that the findings of the present study will help inform future inquiry and current practice on how to best serve this important student group, particularly through high-quality academic advising and other related social, academic, and socio-academic opportunities for first-year and transfer undeclared students.

\section{References}

Anderson, B. C., Creamer, D. C., \& Cross, L. H. (1989). Undecided, multiple change, and decided students: How different are they? NACADA Journal, 9(1), 46-50. 
Ashby, J. D., Wall, H. W., \& Osipow, S. H. (1966). Vocational certainty and indecision in college freshmen. The Personnel and Guidance Journal, 44(10), 1037-1041.

Baxter-Magolda, M. B. (1992). Knowing and reasoning in college: Gender-related patterns in students' intellectual development. San Francisco, CA: Jossey-Bass.

Cuseo, J. (2005). "Decided," "undecided," and "in transition": Implications for academic advisement, career counseling, and student retention. In R.S. Feldman (Ed.), Improving the first year of college: Research and practice (pp. 2748). Mahwah, NJ: Lawrence Erlbaum.

D’Amico, M. M., Dika, S. L., Elling, T. W., Algozzine, B., \& Ginn, D. J. (2014). Early integration and other outcomes for community college transfer students. Research in Higher Education, 55, 370-399. doi: 10.1007/s11162-013-9316-5

Deil-Amen, R. (2011). Socio-academic integrative moments: Rethinking academic and social integration among two-year college students in career-related programs. Journal of Higher Education, 82, 54-91. doi: 10.1353/jhe.2011.0006

Eagan, K., Lozano, J. B., Hurtado, S., \& Case, M. H. (2013). The American freshman: National norms fall 2013. Los Angeles, CA: Cooperative Institutional Research Program and the Higher Education Research Institute at UCLA. Retrieved from http://www.heri.ucla.edu/monographs/TheAmericanFreshman2013.pdf

Gordon, V. N. (1981). The undecided college student: A developmental perspective. Personnel and Guidance Journal, 59, 433-439.

Gordon, V. N. (1998). Career decidedness types: A literature review. The Career Development Quarterly, 46, 386-403. doi:10.1002/j.2161-0045.1998.tb00715.x

Gordon, V. N. (2007). The undecided college student: An academic and career advising challenge (3rd ed.). Springfield, IL: C.C. Thomas.

Gordon, V. N., \& Steele, G. E. (2003). Undecided first-year students: A 25-year longitudinal Study. Journal of the First-Year Experience \& Students in Transition, 15, 19-38.

Handel, S. J., \& Williams, R. A. (2012). The promise of the transfer pathway: Opportunity and challenge for community college students seeking the baccalaureate degree. New York, NY: College Board Advocacy \& Policy Center.

Hansen, M. J., \& Pedersen, J. S. (2012). An examination of the effects of career development courses on career decision-making self-efficacy, adjustment to college, learning integration, and academic success. Journal of the First-Year Experience \& Students in Transition, 24, 33-61.

Holland, J. L., \& Holland, J. E. (1977). Vocational indecision: More evidence and speculation. Journal of Counseling Psychology, 24(5), 404-414. doi:10.1037/00220167.24.5.404

Hu, S., \& Kuh, G. D. (2002). Being (dis)engaged in educationally purposeful activities: The influences of student and institutional characteristics. Research in Higher Education, 43, 555-575.

Jones, L. K., \& Chenery, M. F. (1980). Multiple subtypes among vocationally undecided college students: A model and assessment instrument. Journal of Counseling Psychology, 27, 469-477. 
Kuh, G. D., Gonyea, R. M., \& Williams, J. M. (2005). What students expect from college and what they get. In T. E. Miller, B. E. Bender, J. H. Schuh, \& Associates (Eds.), Promoting reasonable expectations: Aligning student and institutional views of the college experience (pp. 34-64). San Francisco, CA: Jossey Bass/National Association of Student Personnel Administrators.

Legutko, R. S. (2007). Influence of an academic workshop on once-undeclared graduates' selection of a major. College Student Journal, 41, 93-98.

Leppel, K. (2001). The impact of major on college persistence among freshmen. Higher Education, 41, 327-342.

Lewallen, W. (1993). The impact of being "undecided" on college-student persistence. Journal of College Student Development, 34, 103-112.

Lewallen, W. (1995). Students decided and undecided about career choice: A comparison of college achievement and student involvement. NACADA Journal, 15, 22-30.

Martinez, J. A., Sher, K. J., Krull, J. L., \& Wood, P. K. (2009). Blue-collar scholars? Mediators and moderators of university attrition in first-generation college students. Journal of College Student Development, 50, 87-103. doi:10.1353/ csd.0.0053

Miller, B., \& Woycheck, S. (2003). The academic advising implications of the self-directed search and Holland's theory: A study of Kent State University exploratory students. NACADA Journal, 23(1/2), 37-43.

U.S. Department of Education, National Center for Education Statistics. (2014). Table 311.60 Enrollment in postsecondary education, by level of enrollment, level of institution, student age, and major field of study: 2011-12. In U.S. Department of Education, National Center for Education Statistics (Ed.), Digest of Education Statistics (2013 ed.). Retrieved from http://nces.ed.gov/programs/ digest/d13/tables/dt13_311.60.asp.

Palmer, R. T., Davis, R. J., \& Maramba, D. C. (2011). The impact of family support on the success of Black men at an Historically Black University: Affirming the revision of Tinto's theory. Journal of College Student Development, 52, 577-597.

Perry, W. G., Jr. (1999). Forms of intellectual and ethical development in the college years. San Francisco, CA: Jossey-Bass.

Reinheimer, D., \& McKenzie, K. (2011). The impact of tutoring on the academic success of undeclared students. Journal of College Reading and Learning, 41, 2236.

Reynolds, P., Gross, J., Millard, B., \& Pattengale, J. (2010). Using longitudinal mixed-methods research to look at undeclared students. New Directions for Institutional Research, (S2), 53-66.

St. John, E. P., Hu, S., Simmons, A., Carter, D., \& Weber, J. (2004). What difference does a major make? The influence of college major field on persistence by African American and White students. Research in Higher Education, 45, 209232.

Taylor, K. M. (1982). An investigation of vocational indecision in college students: Correlates and moderators. Journal of Vocational Behavior, 21, 318-329. 
Tinto, V. (1993). Leaving college: Rethinking the causes and cures of student attrition (2nd ed.). Chicago, IL: University of Chicago Press.

Titus, M. A. (2006). Understanding college degree completion of students with low socioeconomic status: The influence of the institutional financial context. Research in Higher Education, 47, 371-398. doi: 10.1007/s11162-005-9000-5

Wang, X. (2009). Baccalaureate attainment and college persistence of community college transfer students at four-year institutions. Research in Higher Education, 50, 570-588.

Wanberg, C. R., \& Muchinsky, P. M. (1992). A typology of career decision status: Validity extension of the vocational decision status model. Journal of Counseling Psychology, 39, 71-80. 